\title{
Influence of INM Practices on Overall Growth, Yield and Economics of Andrographis paniculata (Kalmegh) in Pongamia Based Agri-Silvi System
}

\author{
D. Divya Bhargavi, A. Madhavi Lata and A. Srinivas
}

Department of Agronomy, College of Agriculture, Rajenderanagar - 500030, Telangana, India

*Corresponding author

A B S T R A C T

Keywords

Kalmegh,

INM, Pongamia, Plant height.

Article Info

Accepted:

07 September 2017

Available Online:

10 October 2017
An experiment was conducted during Kharif, 2013 with eight different treatments consisting of integration of both organic and inorganic fertilizers in Andrographis paniculata intercropped in Pongamia based Agri silvi system to find out best treatment under Southern Telangana agro climatic zone of Andhra Pradesh. The results revealed that the $\mathrm{T}_{8}(50 \% \mathrm{RDF}+50 \%$ Neem cake) has given highest plant height $(76.9 \mathrm{~cm})$ and even leaf area per plant $\left(217.4 \mathrm{~cm}^{2}\right)$, Dry matter production $\left(503.6 \mathrm{gm}^{-2}\right)$, Fresh $\left(2968 \mathrm{~kg} \mathrm{ha}^{-1}\right)$ and dry (2078 $\mathrm{kg}$ ha $\left.{ }^{-1}\right)$ herbage yield

\section{Introduction}

In India, major agricultural area is under dryland farming and growing of normal field crops is difficult until irrigation facility is provided due to inadequate and lack of timely onset of monsoon. About $70 \%$ of rural population lives in dry farming areas and their livelihood depends on success or failure of the crops. Dryland agriculture plays a distinct role in Indian agriculture occupying $60 \%$ of cultivated area which supports $40 \%$ of human population and $60 \%$ livestock population (Kamal and Yousuf, 2012).

Today, there is a huge shortfall of basic needs besides, an enormous damage to the resources, both renewable and non- renewable on account of their overuse. Thus, to bridge the gaps of supply and demand, efficient management of natural resources is essential. The existing land use systems with separate allocation to agriculture and forest are inadequate to meet the demands for food, timber, fuel, fodder and other minor products in the $21^{\text {st }}$ century.

Intercropping is always preferred as it provides agricultural returns on one hand and results in increased growth rate of tree species on the other due to frequent irrigation and hoeing operations of crops grown under tree canopies and thereby increases the land value.

Under such a situation, an agroforestry system can be practiced which will not only increase the productivity of land but also gives good remuneration to the farmer. An Agroforestry 
system will act as sustainable land management system especially in dry land areas which will maximize the production from unit land area due to integration of trees and agricultural crops. The importance of agroforestry for food, fuel, fodder, fruits, fertilizer, timber etc. and also in conservation of natural resources have been well recognized.

Agri-horticultural system is one such sustainable land management system in dry land areas which will enhance total productivity and farm income per unit area of land and also fulfills the needs of farming community through its diversified outputs such as food, fodder, timber, fuel wood, manure etc.

Diversification and sustainability in production are the two main goals to be achieved through short and long term strategies. There is an immediate need to explore the possibilities of growing commercial tree species with high value cash crops such as medicinal herbs on farm land without compromising quality of the product.

Valuable medicinal herbs are getting exhausted very fast due to their over exploitation by pharmaceutical industry, unscientific collection and illegal export. To reverse this situation, it is necessary that the cultivation of medicinal and aromatic plant species in various agroforestry systems to be exploited at commercial level.

Pongamia pinnata (L.) commonly known as 'Karanja' is a medium sized leguminous tree with short crooked trunk and broad crown spread. It is a member of family Fabaceae, sub family Papilinoideae. $P$. pinnata is an important non-edible minor oil seed tree that grows in semi-arid regions. It is a multipurpose tree species and it is also a good nitrogen fixing tree. This tree is suitable for agroforestry farming because of its fast growth and nitrogen fixing ability and also is best suited tree for energy plantations. The Medicinal and Aromatic Plants (MAPs) are grown under forest cover because most of them are shade tolerant. Andrographis paniculata is such a medicinal plant which can sustain shade, intercropped with tree species. Andrographis paniculata is an annual herb belonging to the family Acanthaceace which is extremely bitter in taste in each and every part of the plant body, hence known as "King of bitters". It tastes bitter due to the presence of colourless crystalline diterpenoid lactone, andrographolide $\left(\mathrm{C}_{20} \mathrm{H}_{30} \mathrm{O}_{5}\right.$ : mp: 230 $239^{\circ} \mathrm{C}$ ). This plant is also known as "rice bitters" in West Indies or "chirella" in England and is used mainly for treating fever, liver diseases, diabetes, snake bite. The leaf and the whole herb contain the medicinal properties. In India it is grown in Assam, Bihar, Karnataka, Kerala, Madhya Pradesh, Andhra Pradesh and West Bengal.

Though the production of the medicinal plants can be increased by supplying the nutrients through chemical fertilizers alone but continuous use of them on long-term basis may lead to the degradation of the soil quality and also affect the medicinal quality. In order to increase the quality of crops especially, medicinal and aromatic plants (MAPs), organic fertilization is more acceptable than chemical fertilizers.

However, complete replacement of inorganic fertilizers by the organic manures is not advisable owing to their low nutrient concentration and in turn requirement in huge quantities which may not be possible due to scarcity of such materials. In this endeavor, a blend of organic and inorganic fertilizers is important not only for increasing yield but also for sustaining soil health and maintaining favorable ecological conditions on long term basis. Organically grown produce of Andrographis paniculata will give a premium price in international market. 


\section{Materials and Methods}

An experiment was conducted during Kharif, 2013 at Students farm, of Department of Farm Forestry, College of Agriculture, Rajendranagar, Hyderabad which is geographically situated at $17^{0} 19^{1} \mathrm{~N}$ latitude, $78^{0} 28^{1}$ E longitude at an altitude of $542.3 \mathrm{~m}$ above mean sea level, under Southern Telangana agro climatic zone of Andhra Pradesh. The soil of the experimental site was sandy loamy in texture, neutral in soil reaction, low in organic carbon, available nitrogen, medium in available phosphorous and potassium.

The experiment was laid out in a randomized block design with eight treatments viz., $\mathrm{T}_{1^{-}}$ Control, $\mathrm{T}_{2}$ - RDF (75: 50: $50 \mathrm{NPK}$ ) of Andrographis paniculata, $\mathrm{T}_{3}$ - Farm Yard Manure@5t/ha, $\mathrm{T}_{4}$ - Vermicompost@2t/ ha, $\mathrm{T}_{5}$ - Neem cake @ $1 \mathrm{t} / \mathrm{ha}, \mathrm{T}_{6}-50 \% \mathrm{RDF}$ $+50 \% \mathrm{FYM}, \mathrm{T}_{7}-50 \% \mathrm{RDF}+50 \%$ Vermicompost, $\mathrm{T}_{8}-50 \% \mathrm{RDF}+50 \%$ Neem cake replicated thrice.

The quantity of inorganic fertilizers and the organic manures were applied as per the treatment. The seeds were sown at a spacing of $30 \times 10 \mathrm{~cm}$. Irrigation was given whenever dry spell occurred. During the crop growth period, rainfall of $475.6 \mathrm{~mm}$ was received in 34 rainy days in 2013 as against the decennial average of $634 \mathrm{~mm}$ received in 35 rainy days, for the corresponding period.

Plant samples of andrographis were collected to record dry matter production at $60,90,120$, 150 DAS and at harvest. The crop was weeded twice to keep the plots weed free at 40 and 60 DAS. The crop was harvested by hand pulling the entire plant after giving light irrigation. After harvesting, fresh herbage yield of the crop was recorded and later dry herbage yields after drying the crop under shade for 15 days.

\section{Results and Discussion}

\section{Effect of INM practices on plant height}

The influence of different nutrient management practices on plant height of andrographis was significant in different treatments. The crop responded more to INM practices rather than inorganic fertilization alone with 75:50:50 kg N, $\mathrm{P}_{2} \mathrm{O}_{5}, \mathrm{~K}_{2} \mathrm{O} \mathrm{ha}^{-1}$. There was a gradual increase in plant height from 60 DAS to harvest. In all the stages of crop, significantly higher plant height was recorded in $\mathrm{T}_{8}(50 \% \mathrm{RDF}+50 \%$ Neem Cake) $(76.9 \mathrm{~cm})$ at harvest over all treatments followed by $\mathrm{T}_{7}$ treatment (50\% RDF $+50 \%$ Vermicompost) $(73.8 \mathrm{~cm})$ which is on par with $\mathrm{T}_{6}(50 \% \mathrm{RDF}+50 \% \mathrm{FYM})(71.2 \mathrm{~cm})$.

It was clearly noticed from the data, that there was marked increase in height of andrographis at all stages of crop growth under different integrated nutrient management treatments over $\mathrm{T}_{1}$ (control). The plant height recorded higher in $\mathrm{T}_{8}(50 \% \mathrm{RDF}$ $+50 \%$ Neem Cake) could be attributed due to the presence of sulphur rich fatty acids which has nitrification inhibition property which prolongs the availability of nitrogen, has lower $\mathrm{C}: \mathrm{N}$ ratio when compared with other bulky organic manures and hence decomposes faster making nutrients readily available to plants. During initial stages of crop, nutrients are readily available through inorganic fertilizers, whereas during later stages of crop the nutrients are supplied by both inorganic as well as organic forms due to decomposition, thus making higher availability of nutrients. Moreover the nutrient concentration of Neem cake is higher when compared to both FYM and Vermicompost and hence higher plant height was recorded in $\mathrm{T}_{8}(50 \% \mathrm{RDF}+50 \%$ Neem Cake) followed by $\mathrm{T}_{7}(50 \% \mathrm{RDF}+$ $50 \%$ Vermicompost). These results were in agreement with the findings of Kamal and Yousuf. (2012) (Table 1). 
Effect of INM practices on leaf area per plant $\left(\mathrm{cm}^{2}\right)$

The rate of increase in leaf area was more between 90-150 DAS, it was however, maximum at 150 DAS. The production of maximum leaf area at $150 \mathrm{DAS}$ can be due to the presence of more number of active leaves at this stage. The decrease in leaf area plant ${ }^{-1}$ beyond 150 DAS may be attributed to the periodical shedding of mature and lower leaves. In line with the present results, the decline in leaf production was reported beyond 150 DAS in Kalmegh by Singh et al., (2001)

Close observation of data indicated that organic manurial treatment i.e., $\mathrm{T}_{5}$ recorded significantly more leaf area plant ${ }^{-1}$ than inorganic fertilizers application treatment i.e., 75:50:50 NPK ha ${ }^{-1}$ and control $\left(\mathrm{T}_{1}\right)$ at all growth stages.

The leaf area plant ${ }^{-1}$ further increased due to INM treatments i.e., $\mathrm{T}_{6}, \mathrm{~T}_{7}$ and $\mathrm{T}_{8}$ than individual manurial treatments. Among all the treatments, $\mathrm{T}_{8}$ has recorded highest leaf area plant ${ }^{-1}\left(217.4 \mathrm{~cm}^{2}\right)$ followed by $\mathrm{T}_{7}$ treatment $\left(207.4 \mathrm{~cm}^{2}\right)$ which is on par with $\mathrm{T}_{6}$ treatment $\left(202.3 \mathrm{~cm}^{2}\right)$ at 150 DAS which is followed by $\mathrm{T}_{5}$ treatment $\left(191.3 \mathrm{~cm}^{2}\right)$.

Leaf area recorded in control was significantly lower as compared to all other integrated nutrient management treatments. The increase in leaf area in neem cake along with inorganic fertilizer treated plot over the rest of the treatments could be due to increase in plant height and production of greater number of branches and photosynthetically active leaves plant ${ }^{-1}$ which were recorded higher in $\mathrm{T}_{8}$ treatment.

These results were in agreement with the findings of Kamal and Yousuf (2012) and Mandal et al., (1994) (Table 2).

\section{Effect of INM practices on dry matter production $\left(\mathrm{gm}^{-2}\right)$}

The dry matter production increased continuously upto 150 DAS thereafter decreased slightly in all the treatments due to shedding of leaves. The increase in dry matter accumulation was due to better translocation of carbohydrates and their utilization for the production of more leaves with increase in age and nutrient application and the cumulative effect of progressive increase in growth parameters. Parashar et al., (2011) reported similar findings (Table 3).

Nutrient management practices influenced the dry matter production of Andrographis significantly at all growth stages. The organic manurial treatment i.e., $\mathrm{T}_{5}$ treatment significantly increased dry matter over control and $\mathrm{T}_{2}$ (fertilizer alone). The treatments comprising combined application of organic and inorganic sources of Nutrients i.e., $\mathrm{T}_{8}$ treatment has recorded higher dry matter production (503.6 $\mathrm{gm}^{-2}$ ) followed by $\mathrm{T}_{7}$ treatment $\left(490.6 \mathrm{gm}^{-2}\right)$ and $\mathrm{T}_{6}$ treatment $\left(484.6 \mathrm{gm}^{-2}\right)$ whereas $\mathrm{T}_{3}\left(445.2 \mathrm{gm}^{-2}\right)$ and $\mathrm{T}_{4}$ $\left(447.5 \mathrm{gm}^{-2}\right)$ treatments are on par with each other. The higher dry matter production was recorded in $T_{8}$ treatment may be attributed to greater number of leaves and branches plant ${ }^{-1}$ owing to availability of more nutrients continuously from both inorganic fertilizer and organic manure i.e., Neem cake. There was an increase of $11 \%$ in dry matter production of $T_{8}$ compared to $T_{2}$ treatment. These results were in agreement with Kamal and Yousuf (2012) who stated that higher dry matter accumulation was recorded with application of various organic matters among all manures, neem cake application has recorded higher dry matter accumulation. Mishra and Aruna (2014) opined that dry matter production of Andrographis has improved significantly with the application of organic manures and their combinations. 
Effect of INM practices on fresh and dry herbage yield of andrographis

The advantage of INM practices in improving the herbage yield over no manuring and RDF was observed. There was a considerable increase in herbage yield with the application of organic manures in the form of FYM, Vermicompost and Neem cake in comparison with inorganic fertilizers or Control. Among the INM treatments, $\mathrm{T}_{8}(50 \% \mathrm{RDF}+50 \%$
Neem cake) gave the highest fresh herbage yield of $2968.9 \mathrm{~kg} \mathrm{ha}^{-1}$ and significantly more than $\mathrm{T}_{7}(50 \% \mathrm{RDF}+50 \%$ Vermicompost $)$ $\left(2610.6 \mathrm{~kg} \mathrm{ha}^{-1}\right)$ and $\mathrm{T}_{6}(50 \% \mathrm{RDF}+50 \%$ FYM) $\left(2591.1 \mathrm{~kg} \mathrm{ha}^{-1}\right)$ treatments while $\mathrm{T}_{1}$ treatment recorded the lowest herbage yield of $1386 \mathrm{~kg} \mathrm{ha}^{-1}$. Similar trend was observed in herbage yield on dry weight basis. The concept of INM and its advantages in enhancing the productivity of andrographis is well proved in present experiment (Table 4).

Table.1 Plant height $(\mathrm{cm})$ of andrographis as influenced by different INM practices

\begin{tabular}{|l|c|c|c|c|c|}
\hline Treatments & 60 DAS & 90 DAS & 120 DAS & 150 DAS & At Harvest \\
\hline T1- Control & 8.3 & 32.6 & 41.6 & 52.0 & 57.4 \\
\hline T2- RDF (75:50:50 NPK) & 11.2 & 37.4 & 48.6 & 59.9 & 65.0 \\
\hline T3- Farm yard manure @ 5 t ha ${ }^{-1}$ & 9.3 & 34.7 & 44.1 & 54.9 & 59.4 \\
\hline T4- Vermicompost @ 2 t ha ${ }^{-1}$ & 10.6 & 36.1 & 46.1 & 57.1 & 62.0 \\
\hline T5- Neem cake @ 1 t ha ${ }^{-1}$ & 12.4 & 39.4 & 51.1 & 62.4 & 68.0 \\
\hline T6- 50\% RDF + 50\% Farm yard manure & 13.5 & 41.1 & 53.5 & 65.0 & 71.2 \\
\hline T7- 50\% RDF + 50\% Vermicompost & 14.3 & 42.4 & 55.5 & 67.5 & 73.8 \\
\hline T8- 50\% RDF + 50\% Neem cake & 15.5 & 44.1 & 58.1 & 70.3 & 76.9 \\
\hline S.Em.土 & 0.35 & 0.45 & 0.76 & 0.85 & 1.05 \\
\hline C.D (P = 0.05) & 1.08 & 1.38 & 2.35 & 2.60 & 3.20 \\
\hline
\end{tabular}

Table.2 Leaf area plant ${ }^{-1}\left(\mathrm{~cm}^{2}\right)$ of andrographis as influenced by different INM practices

\begin{tabular}{|c|c|c|c|c|c|}
\hline Treatments & 60 DAS & 90 DAS & 120 DAS & 150 DAS & At Harvest \\
\hline T1- Control & 25.0 & 45.4 & 153.4 & 463.4 & 433.2 \\
\hline T2- RDF (75:50:50 NPK) & 32.8 & 57.6 & 180.6 & 493.5 & 460.0 \\
\hline T3- Farm yard manure @ 5 t ha $^{-1}$ & 28.6 & 49.4 & 165.3 & 476.2 & 445.2 \\
\hline T4- Vermicompost @ 2 t ha $^{-1}$ & 29.9 & 51.4 & 168.7 & 480.5 & 447.5 \\
\hline T5- Neem cake @ 1 t ha & 35.9 & 63.6 & 192.0 & 506.0 & 472.0 \\
\hline T6- 50\% RDF + 50\% Farm yard manure & 38.9 & 70.6 & 203.6 & 518.9 & 484.6 \\
\hline T7- 50\% RDF + 50\% Vermicompost & 40.0 & 74.6 & 209.6 & 528.6 & 490.6 \\
\hline T8- 50\% RDF + 50\% Neem cake & 42.5 & 82.6 & 223.6 & 544.6 & 503.6 \\
\hline S.Em.. & 0.81 & 1.96 & 3.65 & 4.01 & 3.90 \\
\hline C.D (P = 0.05) & 2.50 & 6.0 & 11.2 & 12.3 & 12.0 \\
\hline
\end{tabular}


Table.3 Dry matter production $\left(\mathrm{g} \mathrm{m}^{-2}\right)$ of andrographis as influenced by different INM practices

\begin{tabular}{|c|c|c|c|c|c|}
\hline Treatments & 60 DAS & 90 DAS & 120 DAS & 150 DAS & At Harvest \\
\hline T1- Control & 25.0 & 45.4 & 153.4 & 463.4 & 433.2 \\
\hline T2- RDF (75:50:50 NPK) & 32.8 & 57.6 & 180.6 & 493.5 & 460.0 \\
\hline T3-Farm yard manure @ $5 \mathrm{tha}^{-1}$ & 28.6 & 49.4 & 165.3 & 476.2 & 445.2 \\
\hline T4-Vermicompost@ $2 \mathrm{tha}^{-1}$ & 29.9 & 51.4 & 168.7 & 480.5 & 447.5 \\
\hline T5- Neem cake@1 tha ${ }^{-1}$ & 35.9 & 63.6 & 192.0 & 506.0 & 472.0 \\
\hline T6- $50 \%$ RDF + 50\% Farm yard manure & 38.9 & 70.6 & 203.6 & 518.9 & 484.6 \\
\hline T7- 50\% RDF + 50\% Vermicompost & 40.0 & 74.6 & 209.6 & 528.6 & 490.6 \\
\hline T8- 50\% RDF + 50\% Neem cake & 42.5 & 82.6 & 223.6 & 544.6 & 503.6 \\
\hline S.Em. \pm & 0.81 & 1.96 & 3.65 & 4.01 & 3.90 \\
\hline C.D $(\mathrm{P}=0.05)$ & 2.50 & 6.0 & 11.2 & 12.3 & 12.0 \\
\hline
\end{tabular}

Table.4 Fresh and dry herbage yield $\left(\mathrm{kg} \mathrm{ha}^{-1}\right)$ of andrographis as influenced by different INM practices

\begin{tabular}{|l|c|c|}
\hline Treatments & Fresh Weight & Dry Weight \\
\hline T1- Control & 1386 & 970 \\
\hline T2- RDF (75:50:50 NPK) & 2167 & 1517 \\
\hline T3- Farm yard manure @ 5 t ha & 1192 \\
\hline T4- Vermicompost @ 2 t ha & 1703 & 1240 \\
\hline T5- Neem cake @ 1 $\mathrm{t} \mathrm{ha}^{-1}$ & 1772 & 1412 \\
\hline T6- 50\% RDF + 50\% Farm yard manure & 2017 & 1813 \\
\hline T7- 50\% RDF + 50\% Vermicompost & 2591 & 1827 \\
\hline T8- 50\% RDF + 50\% Neem cake & 2610 & 2078 \\
\hline S.Em. & 2968 & 55.31 \\
\hline C.D $(\mathrm{P}=0.05)$ & 78.67 & 169.39 \\
\hline
\end{tabular}

Table.5 Uptake of N, P and $\mathrm{K}$ contents $\left(\mathrm{kg} \mathrm{ha}^{-1}\right)$ by andrographis at harvest as influenced by different INM practices

\begin{tabular}{|c|c|c|c|}
\hline Treatments & $\mathbf{N}$ & $\mathbf{P}$ & $\mathbf{K}$ \\
\hline T1- Control & 22.6 & 12.3 & 36.3 \\
\hline T2- RDF (75:50:50 NPK) & 45.5 & 35.3 & 79.1 \\
\hline T3-Farm yard manure @ 5 t ha $^{-1}$ & 28.8 & 20.0 & 59.8 \\
\hline T4-Vermicompost @ $2 \mathrm{t} \mathrm{ha}^{-1}$ & 30.3 & 23.3 & 62.0 \\
\hline T5-Neem cake@1 t ha ${ }^{-1}$ & 35.0 & 29.0 & 66.2 \\
\hline T6- $50 \%$ RDF + 50\% Farm yard manure & 54.5 & 40.3 & 85.7 \\
\hline T7- 50\% RDF + 50\% Vermicompost & 56.7 & 43.6 & 88.7 \\
\hline $\mathrm{T} 8-50 \% \mathrm{RDF}+50 \%$ Neem cake & 62.7 & 48.6 & 91.9 \\
\hline S.Em. \pm & 1.02 & 1.37 & 1.24 \\
\hline C.D $(P=0.05)$ & 3.12 & 4.21 & 3.79 \\
\hline
\end{tabular}


Table.6 Gross, Net returns ( $₹ \mathrm{ha}^{-1}$ ) and B: C ratio of the system (tree + crop) as influenced by different INM practices

\begin{tabular}{|l|c|c|c|c|}
\hline Treatments & $\begin{array}{c}\text { Total gross } \\
\text { returns }\end{array}$ & $\begin{array}{c}\text { Total net } \\
\text { returns }\end{array}$ & $\begin{array}{c}\text { Total cost of } \\
\text { cultivation }\end{array}$ & B:C ratio \\
\hline T1- Control & 24810 & 17775 & 7035 & 1.39 \\
\hline T2- RDF (75:50:50 NPK) & 36867 & 19901 & 16966 & 1.85 \\
\hline T3- Farm yard manure @ 5 t ha & 30209 & 23000 & 7210 & 1.31 \\
\hline T4- Vermicompost @ 2 t ha & 31026 & 24000 & 7210 & 1.29 \\
\hline T5- Neem cake @ 1 t ha ${ }^{-1}$ & 34528 & 28000 & 6528 & 1.23 \\
\hline T6- 50\% RDF + 50\% Farm yard manure & 42800 & 21450 & 21349 & 1.99 \\
\hline T7- 50\% RDF + 50\% Vermicompost & 43254 & 21950 & 21303 & 1.97 \\
\hline T8- 50\% RDF + 50\% Neem cake & 49179 & 23950 & 25229 & 2.05 \\
\hline
\end{tabular}

Fig.1 Photosynthetically active radiation (PAR) $\left(\mu \mathrm{mol} \mathrm{S}^{-1} \mathrm{~cm}^{-1}\right)$ utilised by Andrographis as influenced by different INM practices at $60 \mathrm{DAS}$

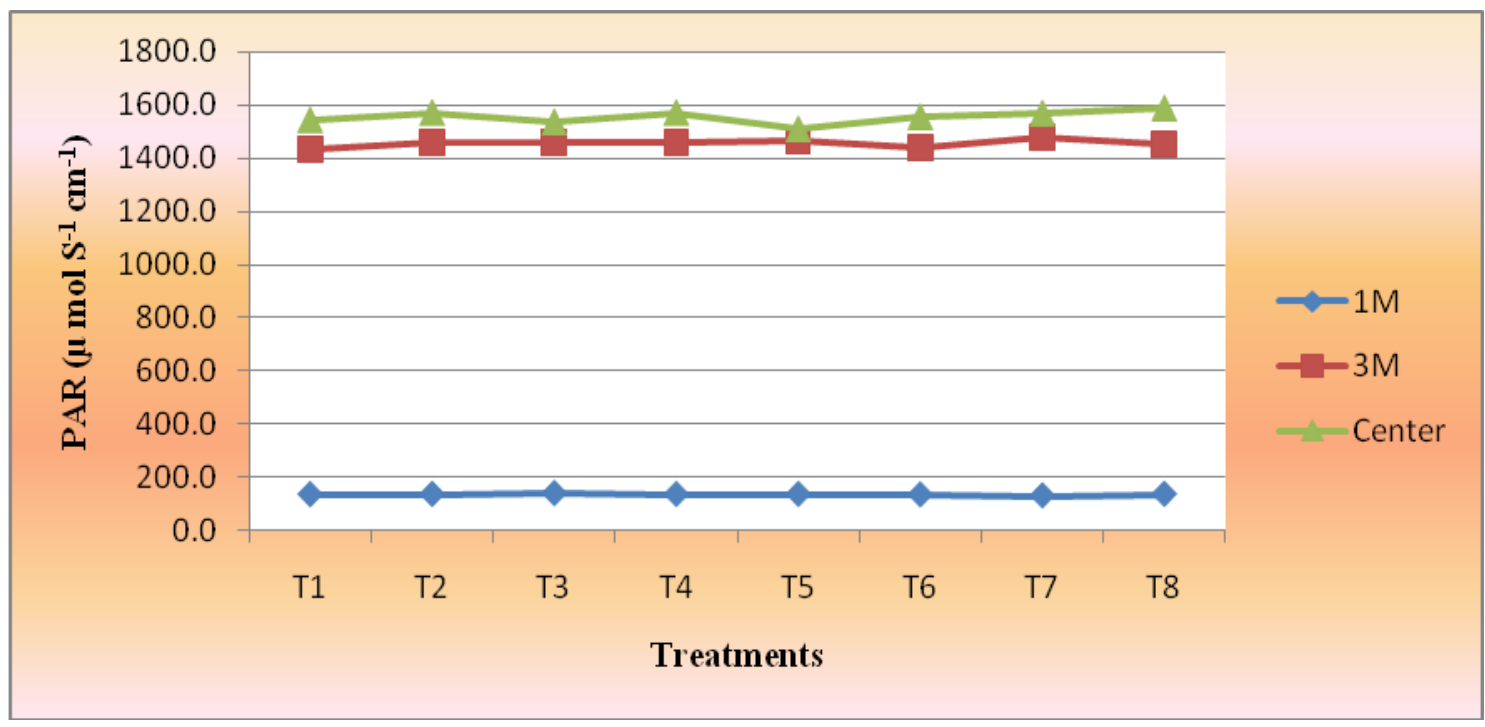

The positive response with the application of Neem cake due to increased plant growth through improvement in soil conditions and increased availability of nutrients favoured higher yields. Organic manuring improves soil physical properties such as reduction in bulk density and increase the water holding capacity. Thus, due to increase in all the growth parameters in neem cake treated plot, the fresh and dry herbage yield was recorded higher in this treatment. These results are in confirmity with the findings of Rizvi et al., (2013), Kavitha and Vadivel (2006) and Ravi Kumar et al., (2013).

\section{Photosynthetically active radiation (PAR)}

Integrated nutrient management treatments did not bring any significant differences in PAR values and the data was analysed statistically.

The influence of different manurial treatments on PAR was inconspicuous. The integrated nutrient management practices did not influence photosynthetically active radiation at all crop stages. The PAR values were recorded at $1 \mathrm{~m}$, $3 \mathrm{~m}$ away from Pongamia tree and also in the center of the plot at different growth stages i.e, 60, 90, 120, 150 DAS and at harvest. Though very less PAR values was recorded at $1 \mathrm{~m}$ 
distance compared to $3 \mathrm{~m}$ and in the center of the plot, due to shade effect of Pongamia tree, however the crop growth of andrographis was not effected due to shade, illustrating that it can be successfully grown under shade in agroforestry systems. These results were in agreement with the findings of Puttanna et al., (2005) and Joy et al., (2004) (Fig. 1).

\section{Nutrient uptake by andrographis}

The data on uptake of nutrients like N, P and K by andrographis as influenced by different nutrient management practices are presented in Table 5.

\section{N uptake}

As regards to $\mathrm{N}$ uptake by the crop, maximum uptake of $62.7 \mathrm{~kg} \mathrm{~N}^{-1}$ was seen in $\mathrm{T}_{8}(50 \%$ $\mathrm{RDF}+50 \%$ Neem cake) and minimum of 22.6 $\mathrm{kg} \mathrm{N} \mathrm{ha}{ }^{-1}$ was observed in control with significant difference among the different treatments.

The higher uptake of nitrogen in $\mathrm{T}_{8}$ treatment was attributed to the high dry matter production in that treatment and also due to the synergistic effect of inorganic fertilizer and organic manure. During initial stages, N was supplied by inorganic fertilizer and during later stages $\mathrm{N}$ was supplied by neem cake due to mineralization at later stages of plant growth.

Similar findings were recorded by Khan et al., (2012).

\section{P uptake}

The influence of different integrated nutrient management practices on $\mathrm{P}$ uptake by plant was significant in all the treatments. Higher $\mathrm{P}$ uptake was observed in $\mathrm{T}_{8}$ treatment (48.6 kg P ha-1) followed by $\mathrm{T}_{7}$ whereas lower uptake was observed in control $\left(12.3 \mathrm{~kg} \mathrm{P} \mathrm{ha}^{-1}\right)$ thus illustrating the importance of integrated management practices compared to control and inorganic fertilizers alone.
The higher uptake of $\mathrm{P}$ in $\mathrm{T}_{8}$ treatment was attributed to the improvement in vegetative and reproductive structures of the plant. Khan et al., (2012) reported similar findings.

\section{K uptake}

Similar trend of $\mathrm{N}$ and $\mathrm{P}$ uptake was observed with regard to $\mathrm{K}$ uptake by andrographis. Higher $\mathrm{K}$ uptake was observed in $\mathrm{T}_{8}$ treatment $\left(91.9 \mathrm{~kg} \mathrm{~K} \mathrm{ha}{ }^{-1}\right)$ whereas lower uptake was observed in control $\left(36.3 \mathrm{~kg} \mathrm{~K} \mathrm{ha}^{-1}\right)$.

Application of neem cake, FYM and vermicompost might have contributed in improving the availability of nutrients because of aggregation of soil particles with more pore space and better aeration resulting in higher uptake of nutrients by the crop. These results were reported by Anwar et al., (2005).

\section{Benefit- cost ratio}

Benefit-cost ratio was influenced considerably due to integrated nutrient management treatments. Among the treatments benefit-cost ratio was maximum in $\mathrm{T}_{8}(50 \% \mathrm{RDF}+50 \mathrm{Neem}$ cake) (2.05) followed by $\mathrm{T}_{7}(50 \% \mathrm{RDF}+50 \%$ vermicompost) (1.97) and $\mathrm{T}_{6}(50 \% \mathrm{RDF}+50 \%$ FYM) (1.99). Minimum benefit-cost ratio was recorded in $\mathrm{T}_{5}(100 \%$ Neem cake) (1.23) due to increase in cost of cultivation. Whereas $\mathrm{T}_{1}$ (control) and $\mathrm{T}_{3}(100 \% \mathrm{FYM})$ treatments are on par with each other with (1.3) benefit-cost ratio (Table 6).

The higher benefit-cost ratio of $\mathrm{T}_{7}$ treatment is due lower cost of vermicompost when compared to neem cake. Usage of organic manures increased the cost of cultivation particularly neem cake and resulted in lesser benefit-cost ratio compared to $\mathrm{T}_{7}$ treatment. These results were in agreement with the findings of Patel et al., (2005).

\section{References}

Anwar, M., Patra, D.D., Chand, S., Kumar, A., Naqvi, A.A and Khanuja, S.P.S. 2005. 
Effect of organic manures and inorganic fertilizer on growth, herb, oil yield, nutrient accumulation and oil quality of Basil. Communications in Soil Science. 36(13-14): 1737-1746.

Joy, P.P., Savithri, K.E., Samuel Mathew and Skaria, B. P. 2004. Effect of shade and spacing on growth, yield and quality of Black musli. (Curculigo orchioides). Journal of Medicinal and Aromatic plant Sciences. 26(4).

Kamal, M.Z.U., and Yousuf, M.N. 2012. Effect of organic manures on growth, rhizome yield and quality attributes of Turmeric (Curcuma longa L.). The Agriculturists. 10(1): 16-22.

Kavitha, C., and Vadivel, E. 2006. Effect of organic manures and inorganic fertilizers on yield and yield attributing characters of Mucuna pruriens. Journal of Medicinal and Aromatic Plant Sciences. 28 : 18-22.

Khan, Z., Tiyagi, S.A., Mahmood, I and Rizvi, R. 2012. Effects of $\mathrm{N}$ fertilization, organic matter and biofertilisers on the growth and yield of Chilli in relation to management of plant-parasitic nematodes. Turkish Journal of Botany. 36(12): 73-81.

Mandal, B.K., Choudhuri, S.K., Sengupta, K and Dasgupta, B. 1994. Response of Betelvine (Piper betle) varieties to organic matter and prilled urea. Indian Journal of Agricultural Sciences. 64(5): 297-301.

Mishra, S., and Aruna, J. 2014. Effect of INM on vegetative growth, flowering and fruiting of Andrographis paniculata. Universal Journal of Agricultural research. 2(3): 93-96.

Parashar, R., Anubha, U., Jasmeet, S., Diwedi, K.S and Khan, A. N. 2011. Morphophysiological evaluation of Andrographis paniculata at different growth stages World Journal of Agricultural Sciences. 7(2): 124-127.

Patel, K.S., Patel, G.N., Patel, M.K., Pathak, H.C and Patel, J.K. 2005. Nitrogen Requirement of rabi Castor (Ricinus communis L.) under different crop sequences. Journal of Oilseeds Research. 22 (1): 209-210.

Puttanna, K., Prakasa Rao, E.V.S., Ganesha Rao, R.S., Gopinath, C.T and Ramesh, S. 2005. Effect of shade and nitrogen on herb yield and longitivity of Patchouli (Pogostemon cablin). Journal of Medicinal and Aromatic plant Sciences. 27(2):

Ravikumar, M., Venkatesha, J., Niranjana, K.J and Gurumurthy, B.R. 2013. Integrated nutrient management on yield and economics of Coleus (Coleus forskohlii Briq.). Karnataka Journal of Agricultural Sciences. 26(1): 119-123.

Rizvi, R., Mahmood, I and Tiyagi, S.A. 2013. Potential role of organic matters and phosphate solubilising bacteria (PSB) on the growth and productivity of Fenugreek. Journal of Agricultural Science and Technology. 15: 639- 647.

Singh, M., Ganesha Rao, R.S and Prakasa Rao, E.V.S. 2001. Land use efficiency, plant growth and yield patterns in Citronella based intercropping system in semi-arid tropics. Journal of Medicinal and Aromatic plant Sciences. 23(3).

Sujatha, S., Ravi, B., Kannan, C and Balasimha, D. 2011. Impact of intercropping of medicinal and aromatic plants with organic farming approach on resource use efficiency in Arecanut (Areca catechu L.) plantation in India. Industrial Crops and Products. 33: 78-83.

\section{How to cite this article:}

Divya Bhargavi, D., A. Madhavi Lata and Srinivas, A. 2017. Influence of INM Practices on Overall Growth, Yield and Economics of Andrographis paniculata (Kalmegh) in Pongamia Based AgriSilvi System. Int.J.Curr.Microbiol.App.Sci. 6(10): 698-706. doi: https://doi.org/10.20546/ijcmas.2017.610.086 